\title{
Pengayaan Literasi Digital di MI Jam'iyyatul Khair: Edpuzzle sebagai Media Alternatif dalam Pembelajaran Daring
}

\author{
Geni Kurniati $^{1}$, Rahmita Egilistiani ${ }^{2}$, Yuli Wahyuni ${ }^{3}$, Christy Tisnawijaya ${ }^{4}$ \\ Universitas Pamulang ${ }^{1234}$ \\ Korespondensi: dosen01935@unpam.ac.id ${ }^{1}$,dosen01439@unpam.ac.id², \\ dosen02313@unpam.ac.id ${ }^{3}$,dosen01357@unpam.ac.id ${ }^{4}$
}

\begin{abstract}
One of the educational institutions in Indonesia that implemented a distance learning system during the COVID-19 pandemic was Madrasah Ibtidaiyah Jam'iyyatul Khair in South Tangerang. As a matter of fact, the teaching staffs at this Madrasah were experiencing difficulties in maximizing online learning. They were dealing with the issues of presenting the online learning materials as well as building students' willingness to engage, thus to study during the online learning process. These constraints were caused by the low interest of students in reading the materials before working on assignments so that it somehow affected student learning outcomes. As a solution, the Community Service Team from Universitas Pamulang held workshop on digital literacy and other dimensions of literacy such as culture and character education. The workshop presented insightful materials on digital literacy and provided practices on how to use Edpuzzle application consecutively. The application was utilized to improve digital media literacy as a means of supporting distance learning. It was designed to make the learning atmosphere more interesting and lively, therefore, students' digital literacy skills would increase concurrently with good character education. By examining the questionnaires - questions spanning from digital literacy to Edpuzzle - that were distributed to participants before and after the workshop, it can be concluded that the Edpuzzle was a new and fun alternative in distance learning for both teachers and students. The teachers gained comprehensive knowledge of digital literacy as well as skills in using the Edpuzzle to make learning materials more fun and educative for students.
\end{abstract}

Keywords: character education, digital literacy, edpuzzle, fabel

\begin{abstract}
Abstrak
Salah satu institusi pendidikan di Indonesia yang menerapkan sistem pembelajaran jarak jauh pada saat pandemi COVID-19 adalah Madrasah Ibtidaiyah Jam'iyyatul Khair di Tangerang Selatan. Staf pengajar di Madrasah ini mengalami kesulitan dalam memaksimalkan pembelajaran daring. Mereka menghadapi kendala dalam menyajikan materi untuk pembelajaran daring yang tidak hanya menambah pengetahuan siswa tapi juga keinginan mereka untuk belajar. Kendala tersebut disebabkan oleh rendahnya minat siswa dalam membaca materi sebelum mengerjakan tugas sehingga berdampak pada hasil belajar siswa. Sebagai solusinya, tim Pengabdian kepada Masyarakat Universitas Pamulang mengadakan lokakarya tentang literasi digital dan dimensi literasi lainnya seperti budaya dan pendidikan karakter. Lokakarya ini menyajikan pemaparan literasi digital dan pemanfaatan aplikasi Edpuzzle untuk meningkatkan literasi media digital sebagai sarana pendukung pembelajaran jarak jauh. Hal ini dirancang agar suasana belajar menjadi lebih menarik dan hidup, sehingga kemampuan literasi digital siswa akan meningkat seiring dengan pendidikan karakter yang baik. Dengan menelaah kuesioner - pertanyaan yang mencakup literasi digital hingga Edpuzzle - yang dibagikan kepada peserta sebelum dan sesudah lokakarya, dapat disimpulkan bahwa Edpuzzle merupakan alternatif baru dan menyenangkan dalam pembelajaran jarak jauh bagi pendidik dan siswa. Para pendidik mendapatkan pengetahuan tambahan mengenai literasi digital serta keterampilan dalam menggunakan Edpuzzle untuk materi pembalajaran yang lebih menyenangkan dan mendidik bagi siswa.
\end{abstract}

Kata kunci: edpuzzle, edukasi karakter, fabel, literasi digital 


\section{A. Pendahuluan}

Literasi digital adalah salah satu dari enam dimensi literasi yang wajib dimiliki untuk dapat bersaing di abad ke-21. Berdasarkan buku Peta Jalan Gerakan Literasi Nasional (Kemendikbud, 2017), enam dimensi literasi tersebut adalah: literasi baca dan tulis, literasi numerasi, literasi sains, literasi digital, literasi finansial, literasi budaya dan kewargaan. Dalam hal ini, literasi bermakna kemampuan membaca, menulis, menganalisis, dan mengaplikasikan. Peningkatan kemampuan literasi digital bagi para pendidik menjadi krusial di masa pandemi COVID-19. Dalam Surat Edaran Nomor 4 Tahun 2020 tentang Pelaksanaan Kebijakan Pendidikan dalam Masa Darurat Penyebaran Corona Virus Disease (COVID-19), Menteri Pendidikan dan Kebudayaan Republik Indonesia, Nadiem Anwar Makarim, mengimbau seluruh pengelola institusi pendidikan untuk menerapkan sistem pembelajaran jarak jauh. Dengan demikian, para pendidik dituntut untuk memperkaya metode belajar pengganti tatap muka di kelas. Sistem pembelajaran jarak jauh ini dikenal dengan sebutan e-learning (electronic learning) yaitu memanfaatkan teknologi internet untuk "memperbaharui, menyimpan, mendistribusi dan membagi materi ajar atau informasi untuk jangkauan luas" (Arnesi \& Hamid, 2015, p. 86).

Literasi digital adalah "pengetahuan dan kecakapan untuk menggunakan media digital, alat-alat komunikasi, atau jaringan dalam menemukan, mengevaluasi, menggunakan, membuat informasi, dan memanfaatkannya secara sehat, bijak, cerdas, cermat, tepat, dan patuh hukum dalam rangka membina komunikasi dan interaksi dalam kehidupan sehari-hari" (Kemendikbud, 2017, pp. 7-8). Keterampilan literasi digital ini, seperti telah disinggung sebelumnya, diperlukan guna menunjang pembelajaran daring (e-learning) di masa pandemi. Adapun pendekatan yang dapat dilakukan guna mencapai literasi digital bagi para pendidik yaitu "pendekatan konseptual" yang meliputi aspek "pengembangan kognitif dan sosial emosional" dan "pendekatan operasional" yang mengarah pada "kemampuan teknis penggunaan media" (Kemendikbud, 2017, pp. 9-10).

Para dosen dan mahasiswa sebagai Tim Pengabdian kepada Masyarakat dari Program Studi Sastra Inggris Universitas Pamulang menyadari pentingnya peningkatan literasi digital bagi para pemangku kepentingan sistem pendidikan. Kami mengamati diperlukannya pelatihan-pelatihan literasi digital bagi para pendidik yang membutuhkan. Hal ini bertujuan untuk meningkatkan keterampilan para pendidik dalam menyajikan materi pengajaran daring kepada siswa. Dengan demikian, baik cara penyajian dan materi yang mendidik dan menarik bagi siswa akan menstimulasi mereka untuk lebih giat belajar.Upaya ini dilakukan untuk mengoptimalkan keterampilan media digital para pendidik sekaligus meningkatkan efektifitas pembelajaran daring siswa. Kompetensi literasi digital bagi pendidik dan peserta didik diyakini memberikan dampak positif bagi pemahaman dan keterampilan dalam pembelajaran melalui media digital. Dengan demikian, baik pendidik maupun peserta didik dapat secara efektif memanfaatkan pembelajaran digital sebagai solusi pembelajaran di masa pandemi ini. Asari et all mengemukakan bahwa "pembelajaran digital perlu diterapkan karena merupakan solusi praktis untuk membangun kompetensi literasi digital bagi guru dan peserta didik, agar terbentuk SDM yang 
memiliki karakter dalam memajukan pendidikan di Indonesia" (2019). Pernyataan ini memperlihatkan bahwa literasi digital dapat dimanfaatkan pula sebagai media pendidikan karakter peserta didik. Adapun pendidikan karakter diperlukan untuk mengahadapi kondisi degradasi moral, etika, dan budi pekerti. Arie Budhiman, Staff Ahli Mendikbud mengemukakan filosofi pendidikan karakter menurut Ki Hajar Dewantara adalah:"olah hati (etika), olah pikir (literasi), oleh karsa (estetika) dan olah raga (kinestetika)" yang meliputi delapan belas nilai-nilai karakter yaitu: "religius, jujur, toleransi, disiplin, kerja keras, kreatif, mandiri, demokratis, rasa ingin tahu, semangat kebangsaan, cinta tanah air, menghargai prestasi, bersahabat/ komunikatif, cinta damai, gemar membaca, peduli lingkungan, peduli sosial, dan tanggung jawab" (2017).

Kedua komponen yang dipaparkan di atas, literasi digital dan pendidikan karakter dalam pembelajaran di abad ke-21, dapat dicapai melalui digital stories (Brenner, 2014). Dalam hal ini, kompetensi literasi digital merupakan media yang sangat bermanfaat karena selain mengasah kemampuan kolaborasi bagi pendidik dan peserta didik, metode pembelajaran ini berhasil mengintegrasikan empat kompetensi dalam belajar bahasa Inggris: mendengarkan, membaca, menulis, dan berbicara.

Salah satu institusi pendidikan di Indonesia yang juga harus melaksanakan sistem pembelajaran jarak jauh di masa pandemi COVID-19 yaitu Madrasah Ibtidaiyah Jam'iyyatul Khair, di Ciputat Timur-Tangerang Selatan. Madrasah Ibtidaiyah Jam'iyyatul Khair merupakan sekolah tingkat dasar yang terdiri dari enam tingkat. Jumlah peserta didik keseluruhan mencapai 422 peserta didik. Adapun jumlah guru tetap Yayasan yaitu 20 orang. Tenaga pendidik di Madrasah ini mengalami kendala dalam memaksimalkan pembelajaran daring. Kendala ini disebabkan oleh rendahnya minat peserta didik untuk membaca materi sebelum mengerjakan tugas memengaruhi hasil belajar peserta didik.

Lebih jauh lagi, Madrasah Ibtidaiyah Jam'iyyatul Khair sebagai mitra PkM memerlukan media penyampaian pendidikan karakter. Semula, pendidikan karakter hadir dalam beragam media pembelajaran seperti dalam materi ajar dan bahkan pendidik berperan menegaskan serta menyimpulkan secara eksplisit pendidikan karakter kepada peserta didik di ruang kelas. Pendidikan karakter ini biasanya disampaikan secara lisan dalam proses belajar tatap muka di kelas. Namun, situasi pandemi menjadi kendala dalam penyampaian pendidikan karakter. Peran pendidik dalam menegaskan pendidikan karakter ini tidak dapat dilakukan ketika situasi pandemi membuat peserta didik harus belajar di/dari rumah.

Berdasarkan latar belakang situasi pandemi COVID-19 yang mengharuskan intitusi pendidikan melakukan sistem pembelajaran jarak jauh dan diperlukannya peningkatan literasi digital sebagai penunjang pendidikan karakter, maka beberapa dosen dan mahasiswa Program Studi Sastra Inggris bekerja sama dengan Lembaga Penelitian dan Pengabdian kepada Masyarakat Universitas Pamulang melakukan kegiatan pelatihan daring bertema "Pengayaan Literasi Digital di MI Jam'iyyatul Khair: Edpuzzle sebagai Media Alternatif dalam Pembelajaran Daring”. Kegiatan pelatihan daring ini adalah keberlanjutan dari kegiatan sejenis yang telah dilakukan pada bulan November 2020 lalu. 


\section{B. Pelaksanaan dan Metode}

Pengabdian kepada Masyarakat ini dilaksanakan di Madrasah Ibtidaiyyah Jam'iyyatul Khair di kota Tangerang Selatan. Dilaksanakan masih dalam kondisi pandemi COVID-19 maka kegiatan ini masih berbasis pertemuan daring. Pertemuan secara daring ini dilaksanakan dengan tujuan tetap terjaganya para peserta $\mathrm{PkM}$ dengan para guru dan staff yayasan Madrasah Ibtidaiyah Jam'iyyatul Khair dalam protokol kesehatan yang seharusnya. Waktu pelaksanaan yang dilakukan oleh para peserta PkM, para dosen dan mahasiswa Sastra Inggris, pada tanggal 28 April 2021 pukul $9.00 \mathrm{~s} / \mathrm{d} 12.00 \mathrm{WIB}$. Pelaksanaan ini dilakukan daring dengan media video konferensi ZOOM.

Sistem pelaksanaan yang digunakan yaitu berupa training atau pelatihan kepada para guru dan kepala sekolah Madrasah Ibtidaiyyah Jam'iyyatul Khair. Hal ini bertujuan agar para guru dan kepala sekolah bisa memahami cara penggunaan aplikasi Edpuzzle sebagai salah satu media pembelajaran yang bisa dimanfaatkan oleh para siswa dalam jarak jauh.

Peserta PkM ini berjumlah 15 orang termasuk para guru juga kepala sekolah. Seperti yang disebutkan di atas bahwa kegiatan ini adalah PkM berbasis daring dengan sasaran peningkatan literasi digital, maka materi yang disampaikan adalah tentang literasi digital berbasis pemakaian aplikasi untuk media pembelajaran. Dikarenakan pelaksanaan PkM ini di sekolah Madrasah Ibtidaiyyah, maka materi yang disampaikan adalah materi yang mudah dipahami seperti cerita binatang atau fabel. Salah satu aplikasi yang dipakai untuk menyampaikan penjelasan literasi digital dalam fabel ini adalah aplikasi Edpuzzle.

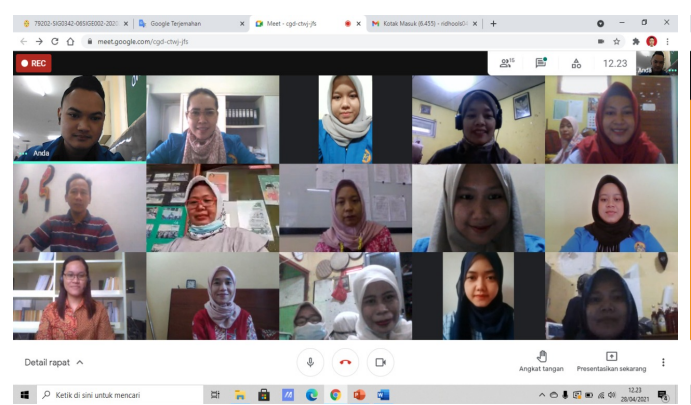

Gambar 1. Narasumber dan Peserta PkM

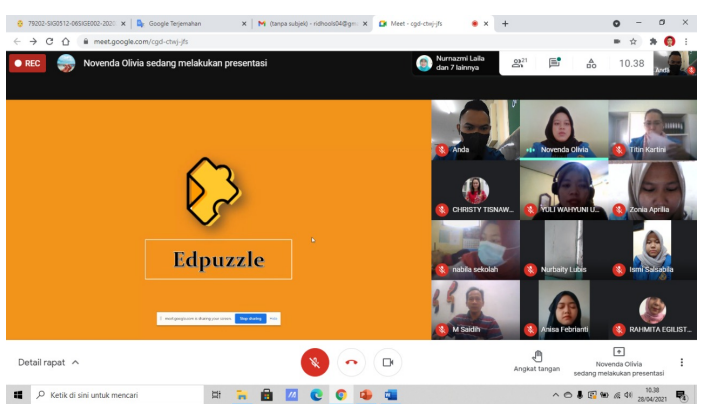

Gambar 2. Pemaparan Materi secara Daring

Gambar 1 merupakan dokumentasi untuk merekam tim PkM Sastra Inggris Universitas Pamulang beserta peserta, para pendidik Madrasah Ibtidaiyah Jam'iyyatul Khair.

Gambar 2 merupakan dokumentasi untuk merekam presentasi Edpuzzle yang sedang berlangsung. 


\section{Hasil dan Pembahasan}

Pandemi Covid-19 membuat perubahan yang cukup signifikan disegala sektor, baik disektor perekonomian maupun pendidikan. Pada sektor pendidikan, hal yang paling terasa perubahannya adalah metode pembelajaran. Jika sebelumnya pembelajaran dilakukan tatap muka di dalam kelas tetapi saat ini dilakukan secara "dalam jaringan" atau online. Hal tersebut membuat metode pembelajaran antar guru dan murid mengalami perubahan yang berhubungan dengan teknologi yang berkembang saat ini.

Metode pembelajaran pada masa pandemi sangat tergantung dengan teknologi internet dan komputer. Guru dan murid bisa berinteraksi dalam satu forum yang sama meskipun berada di rumah masing-masing. Bentuk pembelajaran tidak hanya sekedar bertatap muka dalam sebuah media aplikasi jaringan internet saja tetapi bisa dengan media aplikasi video pembelajaran seperti Edpuzzle. Aplikasi Eduzzle merupkan salah satu media pembelajaran yang mebantu meningkatkan semangat belajar dan kreativitas berpikir peserta didik.

Hasil kegiatan PkM ini menunjukkan bahwa literasi digital sebagai metode pembelajaran saat ini menjadi salah satu solusi terbaik. Hanya saja, permasalahan awal yang dihadapi oleh para guru adalah penggunaan teknologi dan jenis-jenis literasi digital yang akan digunakan pada proses belajar mengajar yang berlangsung secara online. Benar saja, ketika kegiatan ini dilaksanakan, para guru yang mengajar banyak yang belum familiar dengan penggunaan teknologi dan literasi digital. Setelah dilaksanakan pelatihan literasi digital, pemahaman literasi digital para guru meningkat dan diharapkan proses belajar secara online mendapatkan hasil yang optimal.

Kegiatan Pengabdian inimmetakan kemampuan literasi digital para pendidik Madrasah Ibtidaiyah Jam'iyyatul Khair sebelum dan sesudah diberikan pelatihandisusun berdasarkan kuesioner yang telah disiapkan, yaitu kuesioer awal dan akhir. Kuesionar awal berupa pertanyaan mendasar mengenai pengetahuan umum terkait literasi digital dan pengenalan aplikasi pembelajaran. Sedangkan kuesioer akhir adalah hasil pemahaman mengenai literasi digital beserta aplikasi penunjang pembelajaran siswa. Subjek utama dalam penelitian ini adalah guru-guru yang mengajar di sekolah Madrasah Ibtidaiyah Jammiyatul Khair Tangerang Selatan.

\section{a. Kuesioner Awal}

Hasil pada kuesioner awal menunjukkan bahwa para guru di Madrasah Jammiyatul Khair, selanjutnya disingkat MI JK, sudah mengajar dalam kurun waktu di atas tiga tahun. Hal ini berarti tidak ada guru baru yang memulai karir sebagai guru. Hampir semua guru sudah mengajar di atas lima tahun bahkan lebih dari setengah jumlah guru sudah mengajar di MI JK selama sepuluh hingga dua puluh tahun. Tidak mengherankan jika sebelum pelatihan para guru masih belum terbiasa dengan literasi digital beserta jenis-jenisnya.

Sekitar tujuh puluh persen guru merupakan guru kelas yang mengampu beberapa jenis mata pelajaran. Sisanya merupakan guru bidang studi seperti mata pelajaran bahasa Inggris, Matematika, Aqidah Akhlak, dan Alquran Hadist. Mata pelajaran 
yang diampu oleh para guru membutuhkan media pembelajaran online lebih dari satu jenis. Media online yang sering digunakan adalah aplikasi WhatsApp (WA). Setelah dilakukan pelatihan penggunaan media pembelajaran online tidak hanya sebatas aplikasi WhatsApp saja.

Data hasil kuesioner yang didistribusikan sebelum lokakarya menunjukkan sekitar 53\% guru masih kurang paham mengenai literasi digital. Meskipun begitu, guru-guru yang masih kurang paham bukan berarti tidak mengetahui sama sekali tetapi belum mengetahui secara detail cara penggunaan dan fungsi literasi digital. Kemudian, sekitar 40\% guru-guru sudah paham mengenai litarasi digital. Hal ini diasumsikan bahwa guru-guru tersebut sudah memahami fungsi dan cara pengunaan literasi digital. Sisanya sekitar 7\% guru-guru tidak paham sama sekali mengenai literasi digital. Hal ini berarti bahwa hanya sedikit dari guru-guru yang mengajar yang tidak memahami literasi digital. Ini berarti bahwa literasi digital bukanlah halangan besar untuk dijadikan metode pembelajaran selama pandemi Covid-19 berlangsung.

Untuk memahami lebih lanjut pemahaman literasi digital guru-guru di MI JK, maka diberikan pertanyaan mengenai apa itu literasi digital. Hasilnya, mayoritas guruguru memberikan jawaban bahwa literasi digital merupakan membaca secara online atau belajar melalui media online. Hal ini berarti bahwa guru-guru sudah mengetahui secara garis besar mengenai literasi digital. Meskipun begitu, data ini menunjukkan bahwa potensi terbaik literasi digital masih belum dipahami secara maksimal. Literasi digital tidak hanya sebatas membaca secara online belaka tetapi juga media untuk menganalisis, mengitntegrasikan, mengevaluasi informasi dengan orang lain secara efektif. Untuk itu diperlukan pemahaman mengenai literasi digital beserta jenis-jenis dan fungsinya. Inilah poin utama diadakannya pelatihan literasi digital agar pemanfaatan media online guna mendapatkan hasil yang optimal.

Setelah pemahaman mengenai literasi digital, guru-guru diberikan pertanyaan seberpa pentingkah literasi digital. Hasilnya, sekitar $40 \%$ memberikan jawaban sangat penting. Tentunya disaat kondisi pandemi penggunaan literasi digital sangat penting. Terbatasnya pertemuan tatap muka antara guru dan murid tidak akan menjadi halangan yang berarti. kemudian, sekitar $60 \%$ guru-guru memberikan pernyataan bahwa literasi digital adalah penting. Data ini menunjukkan bahwa kesadaran guruguru MI JK sangat tinggi mengenai literasi digital. Hal ini tentunya sebuah respon positif yang sangat bagus agar proses belajar memberikan hasil yang maksimal.

Pemahaman literasi digital tidak hanya sebatas defenisi saja tapi tentunya harus mengetahui jenis-jenisnya juga. Media digital yang seringkali digunakan oleh guruguru MI JK adalah Whatsapp, YouTube, Zoom, Google Meeting dan sejenisnya. Berdasarkan data dari kuesioner awal, sekitar $80 \%$ penggunaan terbesar adalah media sosial seperti Whatsapp, YouTube. Penggunaan terbesar kedua adalah aplikasi konferensi seperti Zoom dan Google Meeting. Keunggulan aplikasi konferensi tentunya bisa bertatap muka dengan banyak siswa diwaktu bersamaan untuk melangsungkan proses belajar mengajar. Penggunan paling sedikit adalah aplikasi ELearning seperti Kahoot, Quizziz, Edpuzzle dan sejenisnya. Sedikitnya penggunaan aplikasi E-Learning di MI JK tentu sudah sewajarnya karena selama ini metode pembelajaran mengikuti metode yang sama dengan sekolah lainnya terkecuali sekolah dengan metode khusus. 
Hasil pencermatan terhadap hasil kuesioner mengungkapkan bahwa guru-guru di MI JK menyatakan bahwa literasi digital merupakan metode pembelajaran yang memudahkan proses belajar mengajar terkhusus dikondisi pandemi Covid19. Semua guru merasa literasi digital bukanlah sesuatu yang sulit diterapkan sebagai metode pembelajaran yang formal. Kemudian, metode pembelajaran melalui E-Learning seperti Edpuzzle memberikan nilai yang sangat positif sebagai metode pembelajaran yang efektif dan efesien. Semua guru memberikan sambutan yang baik mengenai pelatihan literasi digital yang dilaksanakan ini.

Pelatihan kali ini lebih difokuskn pada aplikasi E-Learning seperti Edpuzzle. Aplikasi Edpuzzle merupakan aplikasi pembelajaran dengan pembuatan video yang menarik. Ini bertujuan untuk meningkatkan kreativitas dan pendidikan pembangunan karakter melalui Fabel. Pada pendidikan pembangunan karakter, aplikasi Edpuzzle memberikan poin positif yang cukup baik. Pada kegiatan ini memberikan video animasi mengenai kisah "Burung Gagak dan Rubah". Video animasi dikemas dengan baik dan menampilkan tokoh hewan yang bisa berbicara. Narasi dan dialog dibuat sesuai dengan imajinasi anak tingkatan sekolah dasar. Oleh karena itu, semakin sering digunakannya aplikasi E-Learning seperti Edpuzzle maka akan memberikan dampak yang sangat baik di dunia pendidikan terutama megenai pendidikan pembangunan karakter.

\section{b. Kuesioner Akhir}

Kuesioner akhir merupakan hasil dari pelatihan yang dilaksanakan. Ini merupakan acuan dari pelatihan yang dilaksanakan, apakah memberikan dampak atau tidak. Hasilnya, pelatihan ini memberikan dampak yang sangat baik bagi guru-guru di MI JK. Semua guru menyatakan bahwa literasi digital merupakan metode pembelajaran yang penting terkhusus di era pandemi. Tidak ada satu guru yang menyangkal betapa pentingnya literasi digital saat ini.

Guru-guru di MI JK memberikan penilaian mengenai pemateri yang pada pelatihan kali ini. Data menunjukkan sekitar 91,7\% guru-guru menyatakan bahwa pemateri menyampaikan materi dengan jelas. Sekitar $8,3 \%$ menyatakan kurang jelas dalam penyampaian. Mungkin ada beberapa faktor yang menyebabkan adanya materi yang tidak tersampaikan dengan jelas. Melihat besarnya tanggapan positif mengenai pelatihan ini menunjukkan suksesnya pelatihan yang dilaksanakan kali ini.

Indikasi kesuksesan pelatihan ini selanjutnya adalah semua guru di MI JK menyatakan bahwa tertarik menggunakan literasi digital. Aplikasi E-Learning seperti Edpuzzle sebagai materi utama pada pelatihan kali ini mendapatkan respon yang positif. Sekitar 100\% guru tertarik dan setuju untuk menjadikan aplikasi Edpuzzle sebagai metode pembelajaran selanjutnya. Tentunya ini merupakan sesuatu yang menggembirakan. Hal ini tentunya akan berdampak baik untuk sekolah-sekolah yang belum menggunakan literasi digital sebelumnya. Dampak positif tentunya tidak hanya untuk sekolah tersebut saja tetapi juga untuk sistem pendidikan di Indonesia.

Pada kuesioner bagian akhir, kritik dan saran dari guru-guru MI JK mengenai pelatihan tentu sangat dibutuhkan sebagai bahan evaluasi pelatihan selanjutnya. Pelatihan kali ini mayoritas guru di MI JK menyatakan puas dengan pelatihan ini. 
Banyak ilmu yang didapatkan untuk memajukan metode pembelajaran kedepnnya. Meskipun begitu, ada beberapa gurun memberikan kritik dan saran mengenai langkah-langkah dalam penjelasan fungsi dan penggunaan aplikasi Edpuzzle. Kemungkinan Karena belum terlalu familiar dengan aplikasi Edpuzzle membuat beberapan guru sedikit bingung dengan langkah-langkah penggunaan aplikasi. Semoga dengan banyaknya saran dan bantuan semua pihak akan membuat pelatihan yang lebih baik kedepannya

\section{Penutup}

\section{Simpulan}

Kuesioner umpan balik dari tenaga pendidik sebagai peserta lokakarya di Madrasah Ibtidaiyah Jam'iyyatul Khair menunjukkan bahwa aplikasi Edpuzzle dapat menjadi sarana pembelajaran jarak jauh di era pandemi. Mereka menilai bahwa setelah lokakarya, mereka dapat meningkatan keterampilan digital, terutama aplikasi Edpuzzle, untuk menyajikan materi yang lebih menyenangkan serta mendidik bagi siswa. Bahkan, aplikasi ini menjadi salah satu alternatif yang menarik dan efektif dalam meningkatkan literasi digital dan pendidikan karakter siswa. Sayangnya, kendala koneksi Internet sempat menjadi penghambat kelancaran lokakarya. Meskipun demikian, baik tim $\mathrm{PkM}$ maupun peserta dapat bekerja sama merampungkan lokakarya sehingga kegiatan PkM dapat diselesaikan dengan baik.

\section{Saran}

Dosen dan mahasiswa sebagai bagian dari institusi pendidikan tinggi wajib mendukung program-program Kementrian Pendidikan, salah satunya dalam Gerakan Literasi Nasional. Tim penulis menyarankan untuk diadakannya kegiatan-kegiatan Pengabdian kepada Masyarakat yang sejenis, yaitu pengayaan literasi digital dengan aplikasi yang berbeda dan beragam, guna menunjang proses belajar mengajar jarak jauh khususnya di era pandemi.

\section{Ucapan Terima Kasih}

Penulis sebagai tim Pengabdian kepada Masyarakat dari Program Studi Sastra Inggris Universitas Pamulang mengucapkan terima kasih kepada Yayasan Sasmita Jaya dan Lembaga Penelitian dan Pengabdian kepada Masyarakat Universitas Pamulang untuk dukungan moral dan finansial dalam penyelenggaraan kegiatan ini. Kami juga mengucapkan terima kasih kepada seluruh pihak Madrasah Ibtidaiyah Jam'iyyatul Khair yang telah terlibat dalam kegiatan ini. 
Geni Kurniati, Rahmita Egilistiani, Yuli Wahyuni \& Christy Tisnawijaya

\section{DAFTAR PUSTAKA}

Arnesi, N., \& Hamid, A. (2015). Penggunaan media pembelajaran online - offline dan komunikasi interpersonal terhadap hasil belajar bahasa inggris. Jurnal Teknologi Informasi \& Komunikasi dalam Pendidikan, 2 (1). https://jurnal.unimed.ac.id/2012/index.php/teknologi/article/view/3284

Asari, A., Kurniawan, T., Ansor, S., Putra, A. B. N. R., (2019). Kompetensi literasi digital bagi guru dan pelajar di lingkungan sekolah kabupaten malang. Bibliotika: Jurnal Kajian Perpustakaan dan Informasi, 3 (2). http://journal2.um.ac.id/index.php/bibliotika/article/view/11592/5021

Brenner, K. (2014) Digital stories: A $21^{\text {st }}$-century communication tool for the English language classroom. English Teaching Forum, 1, 22-29. https://americanenglish.state.gov/files/ae/resource_files/52_1_5_brenner.pdf

Budhiman, A. (2017). Gerakan penguatan pendidikan karakter. http://repositori.kemdikbud.go.id/10096/1/Paparan_PPK_Dr_Arie_Budhima n_M_Si.pdf

Kemendikbud (2017). Panduan gerakan literasi nasional. https://gln.kemdikbud.go.id/glnsite/wpcontent/uploads/2017/08/panduangln.pdf

Kemendikbud (2017). Peta jalan gerakan literasi nasional. https://paska.kemdikbud.go.id/wp-content/uploads/2018/08/170823-V.3-GLN.pdf

Kemendikbud (2017). Materi pendukung literasi digital: Gerakan literasi nasional. https:/gln.kemdikbud.go.id/glnsite/wp-content/uploads/2017/10/literasiDIGITAL.pdf

Menteri Pendidikan dan Kebudayaan Republik Indonesia. (2020). Surat edaran nomor 4 tahun 2020 tentang pelaksanaan kebijakan pendidikan dalam masa darurat penyebaran coronavirus disease (covid- 1 9). https://www.google.com/search?q=SURAT+EDARAN+NOMOR+4+TAHUN $+2 \mathrm{O} 2 \mathrm{O}+$ TENTANG+PELAKSANAAN+KEBIJAKAN+PENDIDIKAN+DA LAM+MASA+DARURAT+PENYEBARAN+CO+RO+NAVIRU+S+D $\% 2 F S$ EASE $+($ COVID $-+1+9) \& o q=S U R A T+E D A R A N+N O$ 